\title{
Spatial Differences in Manufacturing Firm Births and Deaths and Local Economic Conditions: Evidence from Pennsylvania
}

\author{
Ismail M. Cole*
}

\begin{abstract}
This study uses county-level manufacturing data (1985-1994) from Pennsylvania to investigate the spatial variation of relationships among manufacturing firm births, deaths, and certain local economic variables suggested by the theoretical literature. To do this, a panel data vector autoregressive method is employed, which, unlike the more customary models of studies of this nature, allows for, among other things, full interdependence among all variables and makes adjustment for omitted-variable bias related to "area-specific" effects. The results, which in some cases confirm and in others contradict those of some of the leading studies on the issue, reveal a rich network of interactions among the variables that indicate that firm births and deaths and local economic conditions are mutually driven. The main conclusion drawn from the results is that firm birth rates and, hence, economic growth, are highest in those counties with: (i) a relatively high proportion of small firms; (ii) lower unemployment; (iii) a growing market demand; (iv) a lower-than-average school property tax rate; ( $v$ ) a higher-than-average quality of public education; and (vi) some urban agglomeration advantages. Some of the implications of the findings for local economic development strategy are considered.
\end{abstract}

\section{INTRODUCTION}

Fan (1994) and others have observed that much of the U.S. regional dynamics literature has focused on regional variations of growth with far less attention devoted to variations within states, and yet, "...the latter defines the disaggregated realities that public officials and policy makers are most concerned with" (Fan 1994, p. 241). This observation motivates the present study. The focus of the study is an issue that, though often ignored, is germane for local growth dynamics considerations (especially in areas undergoing much spatial and industrial restructuring), namely, whether and to what extent the geographic differences in manufacturing firm births and deaths observed within a state drive and are driven by local economic conditions. The issue is investigated in the light of various hypotheses suggested by the theoretical literature, using a panel data vector autoregressive method (cf., Holtz-Eakin, Newey, and Rosen 1988 and Johnson and Parker 1996). This method, while not based on the estimation of a structural model, is a valuable research tool when, as in this study, there is an interest in confirming or questioning the validity of various causal hypotheses. Additionally, the

*Professor of Economics, California University of Pennsylvania, California, Pennsylvania. I am indebted to Madeline Rogers of the Pennsylvania Department of Education for kindly providing some of the data used in this study. I am also grateful to Wanthana K. Horiguchi for providing valuable assistance in collecting and typing the data on firm births and deaths, and to two anonymous reviewers for useful comments and suggestions. 
method provides a framework that allows to be remedied a number of shortcomings that have characterized most prior studies. These shortcomings include the failure to explicitly allow for possible interdependence between firm births and deaths (cf., Evans and Siegfried 1992 and Love 1996); the adoption of the singleequation approach, which assumes that the influences of local economic factors on births and deaths are exogenous and ignores the possibility of feedback effects from the latter to the former (cf., Johnson and Parker 1996); the incorrect treatment of "area-specific" effects that may lead to omitted-variable bias; the use of standard correlation analysis, which cannot distinguish between cause and effect or discriminate among alternative hypotheses; and the application of methods that do not fully capture the lag structure of firm births, deaths, and local economic variables.

The next section presents some background issues relating to the data on (manufacturing) firm births and deaths and then documents Pennsylvania crosscounty variations in such births and deaths for the period under study. This is followed in Section 3 by an outline of a set of hypotheses extracted from the literature that may help explain the causes and effects of these variations. Sections 4 and 5 present the methodology and data sources and the estimation results, respectively, while the final section concludes the paper.

\section{SPATIAL DIFFERENCES IN MANUFACTURING FIRM BIRTHS AND DEATHS}

\section{Background on the Data}

The large effort, time, and expense involved in collecting or acquiring dependable data on firm births and deaths, especially at the subnational level, have forced many researchers and policy makers to rely mostly on readily available but dismally inadequate databases such as those of the Strategic Planning Institute of Boston (SPIB) and the Dunn and Bradstreet market identifier files (DMI) (cf., Williams 1993 and Davis, Haltiwanger, and Schuh 1996). This inadequacy is highlighted in many studies (see, for example, Birley 1986, Kalleburg et al. 1990, and Williams 1993), which show that the DMI, for example, misses anywhere from 12 to 90 percent of new businesses listed in more detailed and cumbersome databases, such as state employment files, the white pages of the telephone book, and business directories.

In this study, county data on manufacturing firm births and deaths are extracted from various issues of the Pennsylvania Industrial Directory (PID), compiled by the Harris Publishing Company in cooperation with the Pennsylvania Department of Commerce. The PID dates from 1982/1983 and it contains a variety of information (year of establishment, product type, sales, number of employees, etc.) on over 18,000 individual manufacturing firms. An attractive aspect of the PID is that it has features that minimize the problems of limited coverage and the tracking of firm births and deaths over time that often plague many data sources. For instance, it is comprehensive in that it obtains data from all known 
official and commercial sources. Also, it updates the data every six months, and verifies all listings on an annual basis. Furthermore, the PID, unlike, for example, the DMI, which sometimes mistakenly codes a relocated firm as a new firm, provides referrals that help identify firms that move or change their names. This is important when one notes that in 1995, for example, 24 percent of the manufacturing firms in Pennsylvania moved and 12 percent changed their names. These virtues, however, are somewhat tempered by the weaknesses of the PID. For example, some firms do not respond to its survey to update information, even though the number of such firms is said to be small. Also, the PID acknowledges that some firms are inadvertently omitted, and that it deletes firms that no longer meet its criteria for inclusion.

In common with many studies, this study identifies firm births and deaths by comparing firm information for two successive years at a time. Specifically, a firm birth is defined as a firm that is listed in a given year but not in the prior year and, likewise, a death is defined as a firm that is listed in a given year but not in the following year. This method produced the data on manufacturing firm births and deaths for the 60 of the 67 Pennsylvania counties for which there were at least one birth and one death for each of the years from 1985 to 1994 . A more detailed description of these data can be found in Cole (1998).

\section{County Differences in Manufacturing Firm Births and Deaths, 1985-1994}

Pennsylvania, as part of the old Northeast-Midwest manufacturing belt, has experienced much industrial restructuring in recent years, as evidenced by, among other things, the substantial drop in manufacturing employment. Between 1986 and 1995, for example, such employment fell from 1,401,467 (27 percent of total employment) to 1,096,048 (19 percent of total employment), a loss of 305,419 jobs, or 23 percent of the 1986 manufacturing workforce (PID 1986 and 1995). Accompanying this decline have been significant changes in the number and growth rates of firm births and deaths. Between 1985 and 1994, there were 16,370 manufacturing firm births and 10,322 firm deaths in Pennsylvania. The net gain of 6,048 firm births accounted for 32 percent of the total number of manufacturing firms at the end of the period. During this period, the annual average number of firm births and deaths for the state were 1,637 and 1,032, respectively, however, the numbers vary substantially across counties. Specifically, the total number of firm births and deaths during the 10-year period ranged from 1,771 and 1,183 in Allegheny, 1,368 and 924 in Montgomery, and 1,139 and 730 in Bucks, to 36 and 23 in Perry, 32 and 22 in Wyoming, and 26 and 25 in Juniata, respectively. The 10 counties with the largest number of firm births and deaths were all Metropolitan Statistical Area (MSA) counties, and they alone accounted for 53 percent and 58 percent of the total firm births and deaths, respectively, during the 1985-1994 period. Also revealed by the data are considerable year-to-year variations in the number of firm births and deaths. In general, however, the trend across the counties seems to be one of a relatively low number of firm births in 1985, which rose 
steadily until 1988, and then dropped sharply thereafter, especially during the 1990-1991 recession years. The opposite is true for firm deaths during the period.

Further insights are provided by the firm birth and death rates. These rates are derived by normalizing the absolute number of firm births and deaths to take account of differences in county size. A number of studies have shown that empirical results can be sensitive to the denominator used in the normalization (see, for example, Garofoli 1994 and Keeble and Walker 1994), therefore, this study computes three alternative firm birth/death rate measures using the following denominators: the county's resident population, civilian labor force, and stock of manufacturing firms.

Table 1 provides the county annual averages of the different measures of firm birth and death rates (each listed in descending order) for the 1985-1994 period. A number of points are noteworthy about this table. First, the measures indicate much variation in firm birth and death rates among the counties. With regard to firm birth rates, for example, the number of firm births per 1,000 resident population (NFBPOP), per 1,000 manufacturing establishments (NFBEST), and per 1,000 civilian labor force (NFBCIV) measures indicate that the highest annual average firm birth rate $(0.236,202.9$, and 0.569 , respectively) exceeds the lowest $(0.055,44.4$, and 0.124 , respectively) by a factor of four. Second, although most of the firm births and deaths occurred in the highly urbanized counties (boldface in Table 1), some of the highest average annual birth and death rates, regardless of the measure considered, are found in nonmetropolitan counties, for example, Jefferson, Mckean, Crawford, Greene, Indiana, and Juniata. The last four of these counties, however, are contiguous to an MSA. Finally, the data in Table 1 are in accord with those of studies showing that the spatial patterns and results depicted by firm birth and death rates are sensitive to the variables used for normalization. This is particularly true in how the measures rank the counties on the basis of the annual average firm birth and death rates. For example, in selecting the ten counties with the highest firm birth rates, the three measures are in unison for only four counties: Mercer, Somerset, Indiana, and Jefferson. Similar discord can be observed among the measures in the selection of the ten counties with the highest annual average firm death rates.

\section{THE CAUSES AND EFFECTS OF COUNTY VARIATIONS IN FIRM BIRTH AND DEATH RATES}

There are numerous factors that potentially can affect and be affected by the wide differences in the county firm birth and death rates documented above. The selection of these factors for the empirical analysis is guided by previous literature and the availability of county-level data. These factors, which are by no means exhaustive, are now briefly discussed.

Recent studies (cf., Johnson and Parker 1994, 1996 and Love 1996) investigating the spatial and temporal interactions between firm births (FBIRTH) and deaths (FDEATH) among U.K. counties have shown that the birth or death of one firm in one time period can influence the birth or death of another in subsequent 


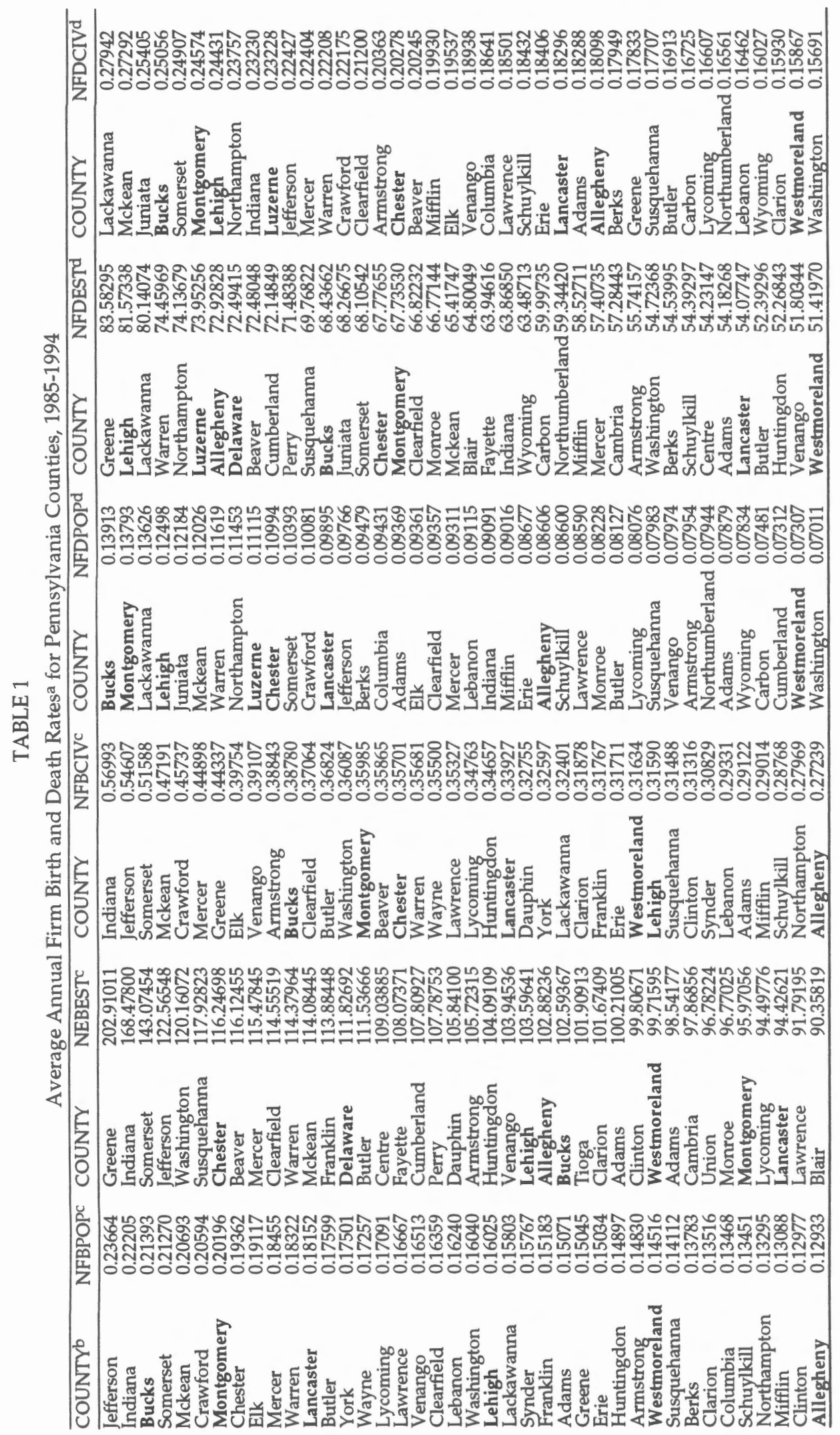




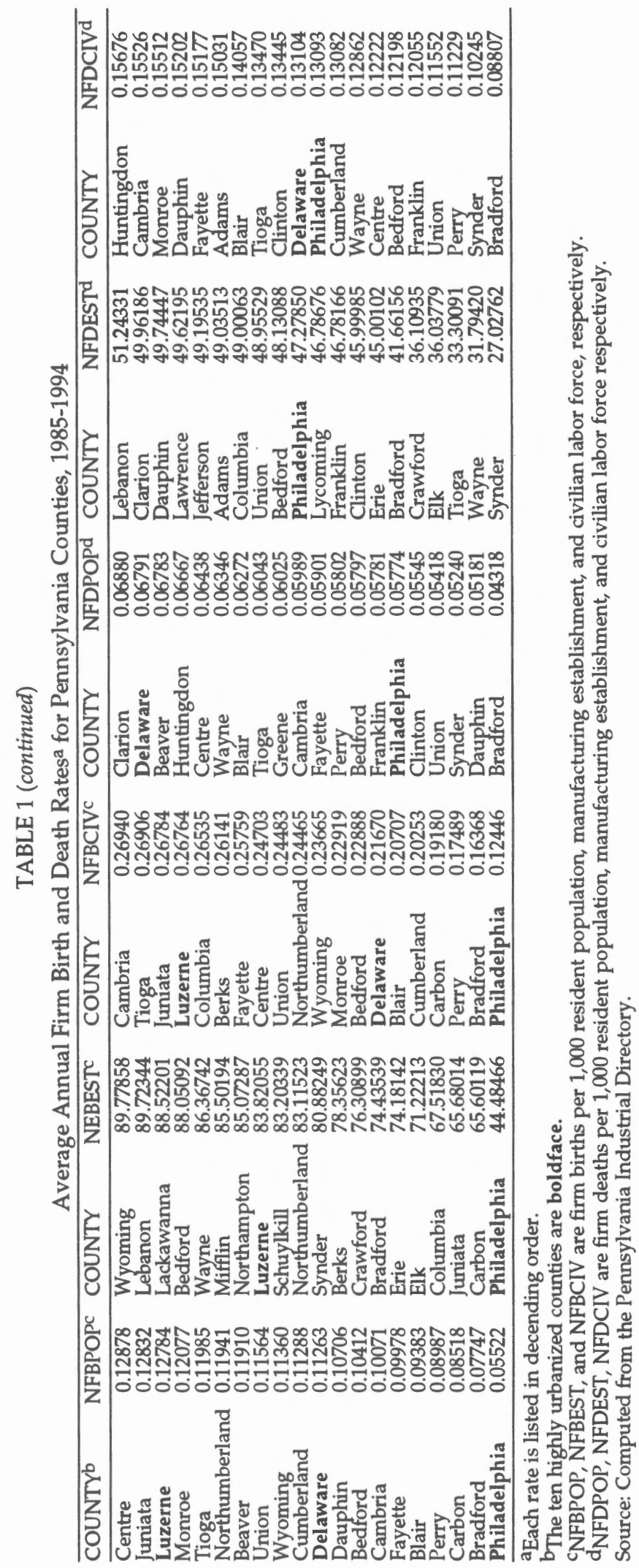


periods, and that this influence may linger for several years. The nature of these interactions is complex, and serves as a source of a number of plausible causal hypotheses, each with important policy implications. One set of these hypotheses suggests that the interactions occur through a multiplier process in which births cause future births and impede future deaths, or deaths cause future deaths and impede future births (the multiplier effect).

These interactions emanate from a number of sources. For example, the birth (death) of a firm can have the effect of increasing (decreasing) the demand for labor which, depending on the spatial labor market conditions, raises (lowers) nominal and real wages and, hence, increases (decreases) output demand. This, in turn, may induce further births (deaths) while at the same time reducing the probability of deaths (births) (cf., Aschroft and Love 1996). These effects are reinforced if, for example, births make the area more attractive to other firms, as well as to consumers (cf., Johnson and Parker 1994), thereby reducing the chances of existing firms going out of business.

Another set of hypotheses regarding firm births and deaths arises from a competitive process in which births cause future deaths and impede future births, or deaths cause future births and impede future deaths (the competitive effect). Here also the channels through which the interactions may occur are varied. For example, firm births can cause deaths in less efficient and innovative firms, especially when product demand is not adequate to accommodate all firms. On the other hand, deaths can increase births and reduce deaths if they lower the price of equipment and other resources required by potential entrants (cf., Storey and Jones 1987). Also, deaths can lead to births because the former increases the pool from which new founders are likely to emerge (cf., Cross 1981) and/or because new firms are attracted to a vacuum left by the firm deaths (cf., Highfield and Smiley 1987, Evans and Siegfried 1992, and Love 1996). Finally, firm births and deaths may interact through the so-called Marshall effect, whereby the birth of a firm ultimately leads to its own death due to age unless it is taken over (cf., Marshall 1949). Clearly, these hypotheses are not mutually exclusive and, thus, the ultimate impact of firm births and deaths on subsequent births and deaths will depend on which of the above effects dominate.

Another factor likely to be of importance in determining spatial differences in firm births/deaths is unemployment. One view (the "recession-push" view, e.g., Oxenfeldt 1943, Highfield and Smiley 1987, and Audretsch and Fritsch 1992) suggests that more unemployment leads to more (less) firm births (deaths) because the unemployed, lacking alternative paid employment opportunities, are more likely to start their own businesses than otherwise similar individuals who are employed. A contrary view (the "demand-based" view, e.g., Keeble and Walker 1994) maintains that higher unemployment is reflective of falling incomes and, hence, reduced product demand which, in turn, lowers (increases) firm births (deaths). The two views are tested for by considering a county unemployment variable (UNEMP), defined as the number unemployed per resident population and, alternatively, per number of manufacturing establishments. 
Employment growth also is thought to affect and be affected by spatial differences in firm births and deaths. For instance, it is widely recognized that firm births cause positive changes in employment (cf., Harris 1983 and Birley 1986). These changes are realized when, for example, firm births respond to increased changes in product demand or general factor supply conditions (cf., Ashcroft and Love 1996).

It can also be argued that a reverse causality from changes in employment to firm births and deaths exists. This can arise when, for example, increased (decreased) employment is accompanied by higher (lower) income and product demand, which increase (reduce) profit opportunities thereby increasing firm births (deaths). Also, increased manufacturing employment increases the pool from which new firm founders are most likely to emerge (Cross 1981). Thus, all else equal, firm births (deaths) should cause positive (negative) changes in employment (EMP), and vice versa. The measures used for EMP are based on the county manufacturing employment scaled by, alternatively, the resident population and the stock of manufacturing firms. Note that EMP and UNEMP will be included as alternatives since both proxy strongly for economic activity.

The size structure of the local industry may also be an important source of spatial differences in firm births and deaths. Specifically, some studies (e.g., Johnson and Cathcart 1979), Whittington 1984 and Fritsch 1992) have shown that areas with a larger proportion of smaller firms tend to have higher birth rates, all else equal (the "seedbed" effect). The reasoning behind this view is that smaller firms act effectively as a "seedbed" for the development of managerial, entrepreneurial, and networking skills of their employees, many of whom, because they are enterprising and for other reasons, go on to start their own businesses. At the same time, however, areas with a relatively high proportion of small firms may have higher firm death rates as well (cf., Gudgin 1978, Healey 1982, and Hall 1987) because such firms are "...inherently vulnerable, high risk and prone to failure" (Keeble and Walker 1994, p. 423) (the high-risk effect). Thus, one expects a positive relationship between the proportion of firms that are small (SFIRM\%) and both firm births and deaths, ceteris paribus. SFIRM\% is measured by the proportion of firms with less than 20 employees.

Spatial differences in labor costs is another potentially significant factor to affect firm births and deaths. Specifically, rising labor costs will impact negatively on both the expected earnings of potentially new firms and the profit levels of existing firms while raising the opportunity cost of operating the firm. As a result, firm births should vary inversely, and death rates directly, with county labor costs (the labor cost effect). Labor costs, however, can be implicated not only as a cause but also as an effect in the firm birth and death process. For example, lower wages may encourage firm births which, through perhaps higher labor demand, bid up wages, thereby offsetting at least a portion of the wage reduction. Hence, wages become endogenous. The proxy for labor costs (average hourly wage, HRWAGE) is the county annual payroll divided by the number of county employees, divided by the 2,000 hours generally worked in a year. 
The market size or demand potential for an area's goods and services, as proxied by, for example, population changes or density (POPDEN), or by real per capita income (INCOME), will exert some influence on firm births and deaths (cf., Keeble and Walker 1994). Specifically, all else equal, areas experiencing an increase (decrease) in either one of these variables should have rising (falling) revenues, rising (falling) profits, and, hence, an increase in firm births (deaths) (the market size effect) (cf., Howland 1988).

Population density and per capita income may also reflect the existence of agglomeration economies, another potential determinant of the spatial variation in firm births and deaths (cf., Carlino 1978 and Wasylenko 1997). Specifically, the clustering of economic activity provides many advantages (e.g., relatively easy and less costly access to customers and a wide range of business services) that are conducive to new firm formation. Indeed, in surveys of firm location decisions, manufacturing executives have consistently ranked these advantages at or near the top of their list of reasons for selecting a firm location (cf., Crone 1997). Not surprisingly, these advantages have, in part, engendered the idea of urban areas being "incubators" of new firms (cf., Hoover and Vernon 1959). Thus, agglomeration economies offer a reason why population density and per capita income should positively (negatively) impact on firm births (deaths), all else equal (cf., Reynolds, Storey, and Westhead 1994).

Population density and per capita income may also reflect the existence of agglomeration economies, another potential determinant of the spatial variation in firm births and deaths (cf., Carlino 1978 and Wasylenko 1997). Specifically, the clustering of economic activity provides many advantages (e.g., relatively easy and less costly access to customers and a wide range of business services) that are conducive to new firm formation. Indeed, in surveys of firm location decisions, manufacturing executives have consistently ranked these advantages at or near the top of their list of reasons for selecting a firm location (cf., Crone 1997). Not surprisingly, these advantages have, in part, engendered the idea of urban areas being "incubators" of new firms (cf., Hoover and Vernon 1959). Thus, agglomeration economies offer a reason why population density and per capita income should positively (negatively) impact on firm births (deaths), all else equal (cf., Reynolds, Storey, and Westhead 1994).

Local taxes raise production costs and, all else equal, will lower the expected earnings of potentially new firms and the profits of existing firms and provide yet another possible cause of the spatial variations in firm birth and death rates. The results of the relatively few studies on the impact of local taxes on firm location and economic activity at the county level have been mixed, however, with findings indicating that the negative impact is either minimal or nonexistent (e.g., Carlino and Mills 1987 and Stafford and Wu 1992), or statistically significant (e.g., Fox and Murray 1990). Most of these studies, however, use highly aggregate tax measures (e.g., total local taxes per capita), which do not account for the fact that local taxes may have differing impacts on firm births and deaths (cf., Kish- 
Goodling 1995). To take this into account, this study disaggregates local taxes into municipal taxes (MUNTAX, that is, municipal property taxes plus county property taxes) and school property taxes (SPTAX). ${ }^{1}$ Also, this study, contrary to the widely accepted view that local taxes affect firm births/deaths and not the other way around, tests for possible interdependency between the two. A reverse causality from firm births and deaths to local taxes may occur for various reasons. For example, the need to alleviate unemployment caused, at least in part by firm deaths, may prompt local policy makers to offer tax incentives to promote new business and employment.

A number of researchers, beginning with Due (1961) and more recently Wasylenko (1997), have observed that firms consider the benefits of the public services made possible by local taxes when making location decisions. Accordingly, these services are controlled for in this study. To do this, three variables, each of which, for obvious reasons, is expected to have a positive (negative) impact on firm births (deaths), are included: (i) the quality of public education provided by the school districts within a county, measured by the instruction dollars spent per student, that is, per average daily membership (PUEDUC); ${ }^{2}$ (ii) per capita spending on police and fire services (POLICE); and (iii) per capita spending on sanitary sewers and sewage treatment and refuse collection and disposal (SEWAGE).

Finally, two dummy variables (DUMURBAN and DUMBORDER) were considered to control for other potentially important factors. Specifically, DUMURBAN is equal to one if the county is in an MSA and DUMBORDER is equal to one if a county borders another state. With regard to the latter, the reasoning is that if Pennsylvania public policies are perceived as more attractive than those of border states, then border counties will experience higher firm birth and death rates, all else equal (cf., Fox and Murray 1990). ${ }^{3}$

\section{METHODOLOGY}

The purpose here is to use an empirical model that will capture the dynamic interrelationships among firm births, deaths, and local economic variables while making no presumption regarding causality, and at the same time cor-

\footnotetext{
${ }^{1}$ Municipal and county property taxes are combined given that they account for a small portion of the firm's total real estate taxes (cf., Kish-Goodling 1995).

${ }^{2}$ As one of the referees pointed out, PUEDUC represents county-level educational effort and not educational output. (e.g., present labor force quality proxied by average educational achievement), which some studies (e.g., Fox and Murray 1990) have shown to be the sole interest of firm. Unfortunately, county-level educational output proxies (e.g., the examination performance of school graduates and the percentage of such graduates proceeding to further education or training) for each of the years under study are not readily available. This problem is not as serious as it might seem, however, because, all else equal, educational output should be positively related to instruction dollars spent per student. As a result, education achievement should be higher in counties with a higher PUEDUC (cf., Bradley and Taylor 1996).

${ }^{3}$ The vector autoregressive model limits the number of variables used in the estimations to avoid the exponential loss of degrees of freedom. This problem, as well as the lack of data, causes some variables that one would like to study to be omitted. One such variable is the local infrastructure or access to a good interstate highway system. However, this omission is not likely to be problematic because some recent studies have shown that the mature stage of development of the U.S. transportation system has made it possible for most areas to offer comparable highway access, thus, such access has become less of a factor in the firm location decision (cf., Forkenbrock and Foster 1996). This is likely to be the case in Pennsylvania where most areas have direct access to an interstate highway. Indeed, the Kish-Goodling's (1995) study on Pennsylvania found that the number of interstate highway miles in a county is only marginally significant in the firm location decision.
} 
recting for the shortcomings of prior studies mentioned earlier. The vector autoregressive (VAR) technique seems well suited to the task. The VAR was initially proposed by Sims (1980) for time series analysis and extended to the panel data context by Holtz-Eakin, Newey, and Rosen (1988). The latter has been successfully applied to the study of firm birth and death dynamics in U.K. counties (Johnson and Parker 1996) but has not previously been employed in a U.S. context.

The VAR model is a simultaneous system of reduced-form equations in which each variable is expressed as a linear function of its own lags and the lags of all the other variables. As such, the VAR eliminates the need to develop an explicit economic model. Also, it does not limit the potential interactions among the variables, and permits the patterns of Granger causality among the variables to be examined. These and other virtues of the VAR, however, are somewhat tempered by its limitations. For example, the number of variables and the length of their lags must be restricted to avoid the exponential loss of degrees of freedom.

Given the discussion in the previous section, the county-level VAR model will employ a system of eleven equations based on the variables: FBIRTH, FDEATH, UNEMP (or EMP), SFIRM\%, HRWAGE, INCOME (or POPDEN), MUNTAX, SPTAX, PUEDUC, POLICE, and SEWAGE. The general form of this model, with "county-specific" effects (that is, unobserved county characteristics related to factors such as location, politics, and resource endowment that help explain county differences in firm birth and death rates) included, can be expressed as the following reduced-form system of equations:

$$
M_{t}=b(L) M_{t}+a+n+e_{t},
$$

where $M_{t}$ is an $11 \times 1$ column vector of the eleven endogenous variables; $a, n$, and $e_{t}$ are $11 \times 1$ vectors of constants, county-specific effects, and white noise error terms; and $b(L)$ is an $11 \times 11$ matrix of lagged polynomial coefficients. The ith and jth elements of $b$ are defined in terms of the lag operator $L$ such that $z_{i j n}(L)=\left(z_{i j 1} L+z_{i j 2} L^{2}+\ldots+z_{i j n} L_{n}\right)$.

In converting the system of equations to estimable form, the following points are noted:

(i) Each variable is entered in its logarithmic, first difference form. This form is important here for several reasons. First, it allows the dependent variables to be interpreted in terms of growth rates without changing any of the predictions made above about the expected signs of the coefficients (cf., Johnson and Parker 1996). Second, first differencing eliminates the "county-specific effects," which would have been omitted had the data been in the level form, thereby biasing the estimates (Holtz-Eakin, Newey, and Rosen 1988). Finally, first differencing eliminates unit roots and common trends in the data, thus avoiding the spurious regression problem (Granger and Newbold 1974).

(ii) The constants in the vector a are time-varying intercepts that control for macroeconomic influences that simultaneously affect the counties. 
Alternatively, a time dummy variable for each year (minus one) in the sample will be included in the equations for a similar control.

(iii) The estimates of the system of equations will be used in examining the patterns of Granger causality among the variables.

(iv) Holtz-Eakin, Newey, and Rosen (1988) have shown that the identifying assumptions of a panel data symmetric VAR such as Equation 1 are simply standard orthogonality conditions that rule out correlations between the error terms and the variables, and that the system can be estimated equation by equation. However, such estimation, if done by OLS, is efficient only if each equation has the same right-hand side variables. This requirement is followed below.

\section{EMPIRICAL RESULTS}

The data sample used in this study is obtained by pooling time series and cross section information from 60 Pennsylvania counties for the 1985-1994 time period ( 600 observations which, due to the use of first differences and lagged variables, are reduced to 420 usable observations). ${ }^{4}$ All variables (except the dummy variables) used in the estimations, along with the descriptive statistics and data sources, are shown in Table 2. All estimations were performed using the RATS econometric package.

To test the robustness of the empirical results, many versions of the model were estimated based on the three alternative measures of firm birth rates and death rates and five different indicators of economic activity or performance: per capita real personal income, the number unemployed per resident population and per stock of manufacturing establishments, manufacturing employment per resident population, and stock of manufacturing establishment. Despite the variety of variables used for the above measures, however, the results are not qualitatively different in that they yield similar inferences for the different versions of the model. The model providing the best overall fit for the data is used as the basis of the causality tests to be presented. This preferred model includes the number of firm births per 1,000 resident population, the number of firm deaths per 1,000 manufacturing establishments, and the number unemployed per stock of manufacturing establishments. The model's parameter estimates may be difficult to interpret due to the reduced-form nature (cf., Sims 1980) and are not directly needed for the causality tests analysis to follow, but are nonetheless reported in Table 3.

Heteroskedasticity is likely to be a problem in the panel data context (cf., Holtz-Eakin, Newey, and Rosen 1988) and it is tested for here using White's (1980) test. Specifically, the residuals estimated from each of the equations are squared and then regressed on all the variables, their squared values, and their cross products. The values of the test statistics obtained (sample size times $\mathrm{R}^{2}$ ) are then compared to the critical chi-squared value (88.3) with 64 degrees of freedom for the $1 \%$

${ }^{4}$ The years (1985-1994) provide adequately diverse economic conditions under which the model is estimated (for example, high economic growth in 1988, a recession in 1990-1991, and moderate growth in 1992 and 1994). 
level of significance. It is revealed that the former is greater than the latter for the FBIRTH, UNEMP and INCOME equations, for which, therefore, the null hypothesis of homoskedasticity is rejected. For these equations, heteroskedasticity was corrected for using White's (1980) method.

TABLE 2

Descriptive Statistics and Data Sources

\begin{tabular}{lcccccc}
\hline Variable & Obs & Mean & Std Error & Minimum & Maximum & Data Source $^{a}$ \\
\hline Firm Birth Rates: & & & & & & \\
NFBPOP & 600 & 0.14678 & 0.10802 & 0.01604 & 0.65018 & HPID \\
NFBEST & 600 & 99.6105 & 72.4262 & 9.90099 & 674.157 & HPID \\
NFBCIV & 600 & 0.31794 & 0.24453 & 0.03076 & 1.72413 & HPID
\end{tabular}

Firm Death Rates:c

$\begin{array}{lcccccc}\text { NFDPOP } & 600 & 0.08357 & 0.05135 & 0.00826 & 0.38842 & \text { HPID } \\ \text { NFDEST } & 600 & 57.9931 & 38.5638 & 4.13223 & 294.642 & \text { HPID } \\ \text { NFDCIV } & 600 & 0.17851 & 0.10909 & 0.01739 & 0.71823 & \text { HPID }\end{array}$

Unemployment/Employment:d

$\begin{array}{llccccc}\text { UNEMPPOP } & 600 & 0.03345 & 0.00849 & 0.00232 & 0.06299 & \text { PLFS } \\ \text { UNEMPEST } & 600 & 24.3473 & 12.4953 & 2.08378 & 162.15 & \text { PLFS } \\ \text { EMPPOP } & 600 & 0.10518 & 0.04236 & 0.01076 & 0.30061 & \text { PLFS } \\ \text { EMPEST } & 600 & 70.0456 & 25.3702 & 17.475 & 195.049 & \text { PLFS }\end{array}$

Agglomeration Economies:e

\begin{tabular}{|c|c|c|c|c|c|c|}
\hline POPDEN & 600 & 193.229 & 601.026 & 13.7261 & 4823.45 & $\mathrm{CCE}$ \\
\hline INCOME & 600 & 12539.4 & 2402.09 & 8883.14 & 23360.0 & PSA \\
\hline
\end{tabular}

Small Firms:f

$\begin{array}{lcccccl}\text { SFIRMS\% } & 600 & 60.5816 & 8.66924 & 36.1445 & 97.9381 & \text { PBCP } \\ & & & & & & \\ \begin{array}{l}\text { Labor Costs:g } \\ \text { HRWAGE }\end{array} & 600 & 9.38208 & 1.73919 & 3.76602 & 15.1473 & \text { PBCP } \\ & & & & & & \\ \text { Local Taxes:h } & & 0.02053 & 0.00326 & 0.00744 & 0.03209 & \text { SRDEMPSD } \\ \text { SPTAX } & 600 & 5.67402 & 2.34153 & 1.691 & 15.475 & \text { LGFS } \\ \text { MUNTAX } & 600 & 500 & & & \end{array}$

Local Public Services:i

\begin{tabular}{llccccl} 
POLICE & 600 & 36.8519 & 31.0914 & 4.47423 & 253.519 & PLGFS/PSDC \\
PUEDUC & 600 & 3736.52 & 828.847 & 1812.88 & 6675.28 & SEDPPS \\
SEWAGE & 600 & 26.5764 & 79.886 & 0.66726 & 1942.81 & PLGFS/PSDC \\
\hline
\end{tabular}

aHPID: Harris Pennsylvania Industrial Directory; PLFS: Pennsylvania Labor Force Series; CCE: County and City Extra; PSA: Pennsylvania Statistical Abstract; PBCP: Pennsylvania Business County Patterns; SRDEMPSD: Selected Revenue Data and Equalized Mills for Pennsylvania School Districts; LGFS: Local Government Financial Statistics; PLGFS/PSDC: Pennsylvania Local Government Financial Statistics and the Pennsylvania State Data Center; SEDPPS: Selected Expenditure Data for Pennsylvania Public Schools.

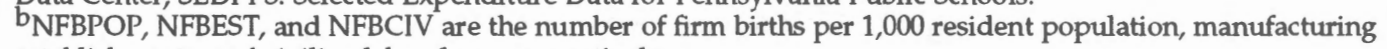
establishments, and civilian labor force, respectively.

CNFDPOP, NFDEST, and NFDCIV are the number of firm deaths per 1,000 resident population, manufacturing establishments, and civilian labor force, respectively.

dUNEMPPOP and UNEMPEST are the number unemployed per resident population and manufacturing establisment; EMPPOP and EMPEST are manufacturing employment per resident population and manufacturing establishment.

ePOPDEN is population density; INCOME is the real per capita personal income.

$\mathrm{f}_{\text {SFIRM } \%}$ is the percentage of firms with less than 20 employees.

gHRWAGE is the average county hourly wage.

hSPTAX and MUNTAX are average school property taxes and municipal taxes, respectively.

iPOLICE is real per capita spending on police and fire services; PUEDUC is instruction dollars per student; and SEWAGE is the real per capita spending on sewers and refuse. 
In testing the various causal hypotheses concerning firm births, deaths, and local economic factors, three issues are focused upon: (i) the direction of the causality, if any, between the variables; (ii) the strength (significance level) of the causal relationship; and (iii) the signs of the sums of the regression coefficients underlying any causal relationship that is revealed.

All three issues are addressed by the Granger causality test results (obtained by F-tests based on the null hypothesis that the set of lags in the explanatory variable is equal to zero) reported in Table 4 . In this table, the dependent variables are placed at the head of the column and the marginal significance levels of the F-tests for the explanatory variables are found by reading down the column. A positive or a negative sign beside the marginal significance level indicates the sign of the sum of the relevant regression coefficients, and it is shown only for those variables that are significant at the $10 \%$ level or higher.

The results in Table 4 are now employed to briefly assess the evidence for or against the causal hypotheses under investigation. The firm birth equation (FBIRTH) shows that there exists a strong negative effect of firm deaths on births, indicating the presence of the multiplier effect. Clearly, this finding does not support the view alluded to earlier that deaths lead to births because the former increases the pool from which new founders are likely to emerge (cf., Cross 1981), or because new firms are attracted to a vacuum left by the firm deaths (cf., Evans and Siegfried 1992 and Love 1996). Rather, the finding suggests perhaps some kind of a "demonstration effect" or what might be termed a "discouragement effect." That is, firm deaths, by reducing the (perceived) attractiveness of an area's business environment, discourage potential new firm founders from locating in the area.

Judging from the firm birth (FBIRTH) and death (FDEATH) equations, the competitive effect receives quite strong support from the data. Specifically, past increases in births and deaths reduce current births and deaths, respectively. This may occur if, for instance, new firms discourage potentially new founders who may think that there is not enough room for them in the market.

The results from the birth and death equations are of interest also because they show that while deaths impact negatively on births, there is little reverse causality from births to deaths since the level of significance in the latter is only at the $18 \%$ level. This lack of a strong and direct interdependence between births and deaths is in accord with the findings of Johnson and Parker $(1994,1996)$ for U.K. counties but in disagreement with those of Love (1996) for the same U.K. counties. The lack of a direct effect from births to deaths, however, does not preclude indirect effects. For example, births strongly affect the unemployment variable (UNEMP), which, in turn, strongly affects deaths (significant at the $1 \%$ level).

The unemployment variable (UNEMP) has no direct impact on firm births (significant only at the $79 \%$ level). However, the results reveal a number of indirect channels of influence. For example, the unemployment variable impacts strongly and positively on firm deaths ( $1 \%$ significance level), which, as already 


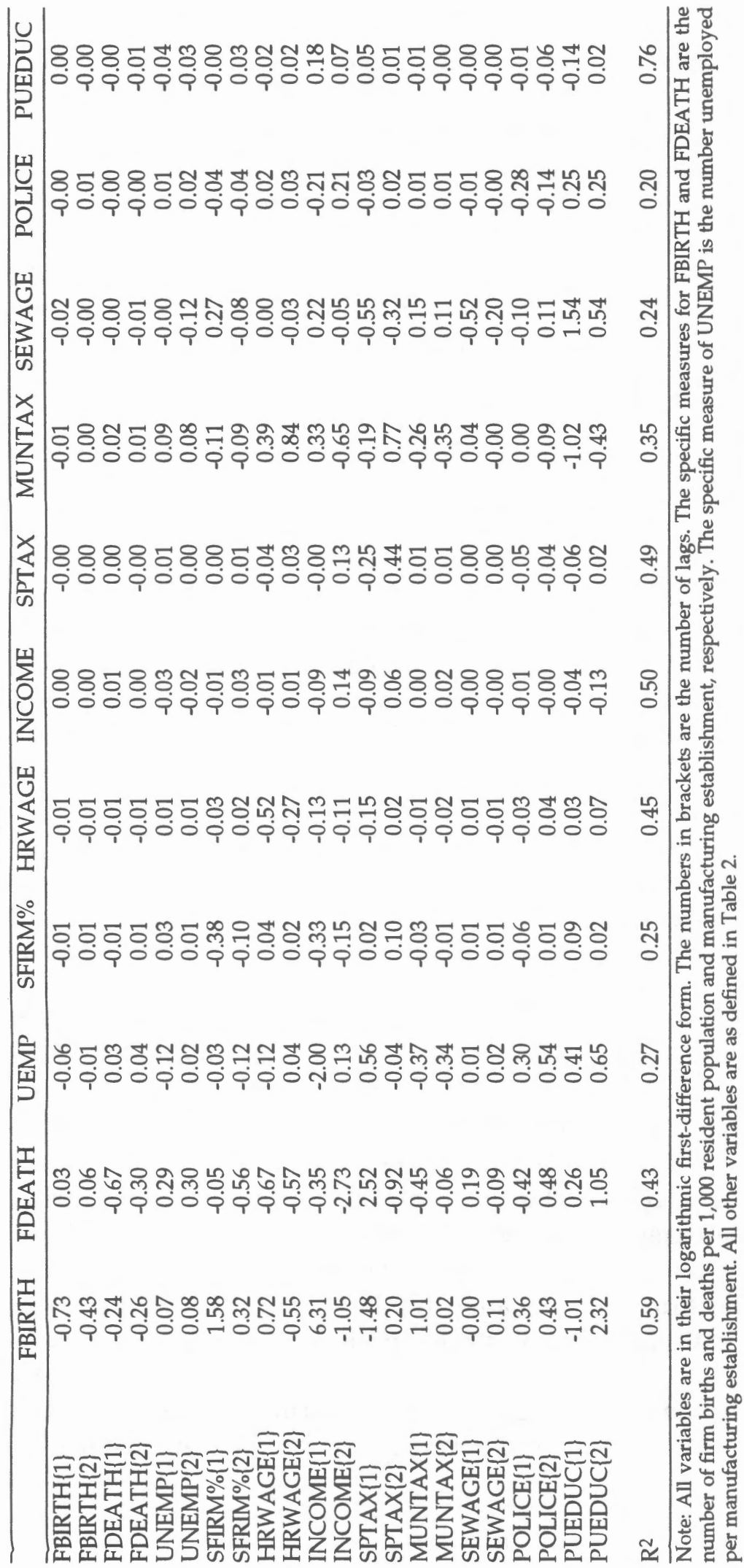


noted, exert a strong negative influence on firm births. Also, unemployment strongly depresses real per capita personal income, ultimately reducing firm births through the market size effect. These results call into question the "recession-push" view, in which increases in unemployment will lead to more firm births. However, the results are fully consistent with the "demand-based" view of the unemployment-firm birth relationship, namely, that counties with higher unemployment rates may be expected to have lower firm birth rates. This conclusion contrasts with the finding of Highfield and Smiley (1987) for the U.S. economy but accords with those of Reynolds (1994) on firm dynamics and economic growth in U.S. metropolitan areas.

Although the causal effect from unemployment to firm births is quite weak, the reverse causal effects from firm births and firm deaths seem highly significant. Indeed, firm births (FBIRTH) and deaths (FDEATH) play a significant counteracting role in the unemployment equation, that is, the former lowers unemployment, while the latter raises it.

The firm birth equation (FBIRTH) shows that the proportion of manufacturing firms with less than 20 employees (SFIRM\%) impacts positively on firm births ( $4 \%$ level of significance). In other words, counties dominated by small firms are likely to have relatively higher firm birth rates. This result provides strong support for the small firm "seedbed" hypothesis, and it is consistent with the results of previous research (for example, Johnson and Cathcart 1979 and Fritsch 1992). No support is found for the high-risk effect since the county's proportion of small firms (SFIRM\%) is significant only at the $49 \%$ level in the firm death equation.

The average county hourly wages (HRWAGE) have little direct impact on firm births (only $13 \%$ significance level) and firm deaths (only $28 \%$ significance level). These results are somewhat surprising given the emphasis that is often placed on labor costs as a key factor in the firm location decision. However, Reynolds, Storey, and Westhead (1994) also found similar results in their analysis of firm births and deaths in U.S. metropolitan areas. Note, however, that the impact of average hourly wages on firm births may be felt through an indirect channel, namely, municipal taxes.

Surprising also is that neither firm births nor firm deaths affect county hourly wages, given that they are often put forth as a channel through which labor costs are affected. In fact, these wages seem to be influenced only by previous changes in wages and average school property taxes.

The firm birth equation (FBIRTH) shows that real per capita personal income (INCOME) has a strong positive impact on firm birth rates. Since INCOME is a proxy for, among other things, market size and agglomeration economies, the results suggest that firm birth rates vary directly with such size and economies, thus lending strong support to the view that urban areas are good 


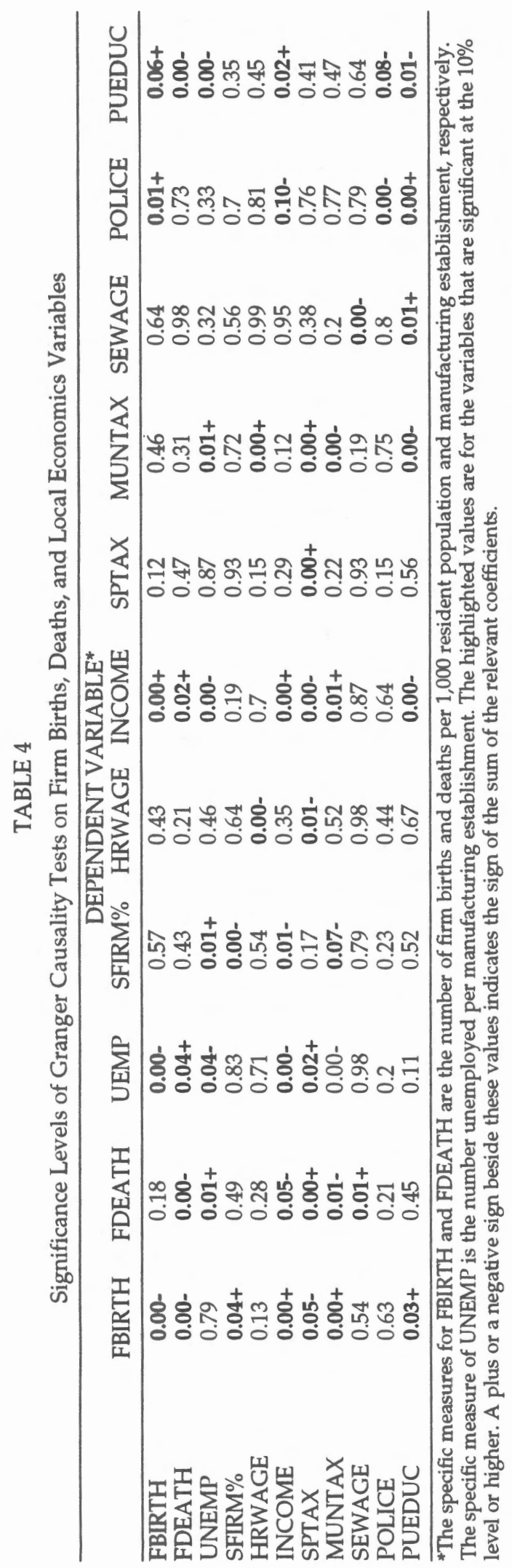


incubators for new firms. ${ }^{5}$ This finding is consistent with, among others, that of Kish-Goodling (1995) on manufacturing firm births in Pennsylvania counties. ${ }^{6}$

Average school property tax rates (SPTAX) have the expected negative impact on firm birth rates, a result reinforced by the finding that such rates have a strong positive impact on firm deaths. As Kish-Goodling (1995) noted, such results are hardly surprising given that a Pennsylvania firm's school property taxes account for over 75 percent of its total property taxes. One conclusion from all of this is that counties with rising average school property taxes are more prone to firm deaths.

Of puzzling nature is the result that municipal taxes (MUNTAX) (insignificant in the Kish-Goodling 1995 study) are likely to generate relatively higher firm births. One possible explanation for this may be that higher municipal tax rates reflect higher levels of public good benefits, which should, in turn, encourage firm births. However, this explanation is premature because the proxies for such benefits (real per capita spending on police and fire services, POLICE, and on sewage and refuse, SEWAGE) have little impact on firm birth rates since they are significant only at the $63 \%$ and $54 \%$ levels, respectively. Thus, the basis of the positive impact of municipal taxes on firm birth is unclear.

The results also show that county average school tax rates (SPTAX) are explained by their own previous changes and may be considered exogenous since there is no evidence of a significant direct effect from the other variables. This finding, together with the fact that the firm birth and death variables are not significant in the municipal tax equation, lend strong support to the conventional view that local taxes affect firm births and deaths and not the other way around.

The average instruction dollars spent per student (PUEDUC), a proxy for the quality of public education provided by the school districts in a county, exerts the expected positive effect on firm births (significant at the $3 \%$ level). This result strengthens the view that firms, prompted by the desire for a skillful and productive workforce, consider educational quality and all other educational benefits derived from school real estate taxes when making location decisions (cf., McNamara, Kriesel, and Deaton 1988 and Kish-Goodling 1995).

As already noted, real per capita spending on police and fire services, and on sanitation and sewage services, has little impact on firm births. Contrary to expectations, however, the latter services, a proxy for a public good benefit, have a strong positive impact on firm deaths, paralleling Kish-Goodling's (1995) results, which show that these services have a negative effect on manufacturing firm births. This unexpected finding is likely to be explained by Kish-Goodling's (1995) suggestion that the services may be proxying for poor water quality or high congestion and, thus, firms perceive it as a cost of location and not a public good benefit. Therefore, counties with higher per capita spending in sanitation and sewage services will tend to have higher firm death rates.

${ }^{5}$ The other proxy for agglomeration economies, population density, was also positive and significant (not shown in the results).

${ }^{6}$ The Kish-Goodling (1995) study also examines firm location decision and economic development in Pennsylvania counties, however, that study and the present one differ in terms of methodology, time period, variables, and some of the data sources employed. Where feasible, however, the results from the two studies will be compared. 


\section{SUMMARY AND CONCLUSIONS}

This paper empirically tested a number of hypotheses chosen to examine the issue of whether the spatial variations in manufacturing firm births and deaths drive and/or are driven by local economic factors in Pennsylvania counties during the 1985-1994 period. This is accomplished by adopting a panel data vector autoregression method (Holtz-Eakin, Newey, and Rosen 1988), which corrected for many of the shortcomings of most previous studies. The method-produced results that withstood a number of tests for robustness based on a variety of measures of firm birth, firm death, and local economic variables. However, the conclusions drawn from these results, while instructive, must be taken with caution given the limitations of the VAR. The conclusions are summarized as follows:

(i) Instead of being causally independent, as is implicitly assumed in most previous studies, firm births and deaths are actually linked in a unidirectional causality in which deaths reduce future births, due perhaps to, among other things, the "discouragement effect."

(ii) Firm births and deaths exert a strong negative influence on future births and deaths, respectively, as the competitive effect contends.

(iii) Overall, significant feedback effects exist between firm births and deaths and local economic performance as measured by, for example, real per capita personal income and unemployment.

(iv) Contrary to the "recession-push" effect but consistent with the demandbased view, counties with higher unemployment rates may be expected to have lower firm birth rates.

(v) Counties with a higher proportion of smaller firms tend to have higher firm birth rates as the "seedbed" hypothesis maintains.

(vi) Counties with relatively high and rising school property tax rates are more prone than other counties to firm deaths.

(vii) Counties with school districts that provide a higher quality of public education tend to have higher firm birth rates.

(viii) Local taxes (school property and municipal taxes) affect firm births and deaths and not the other way around.

(ix) Relatively easy and less costly access to customers and the availability of a wide range of business services, as reflected by the presence of agglomeration economies, stimulate firm births as the "incubator" hypothesis contends.

(x) Labor costs, as proxied by average hourly county wages, are only weakly associated with firm births and deaths.

Some interesting implications for policy can be drawn from the results. One of these relates to the findings of positive feedback effects between firm births and local economic activity, and the negative impact of school property taxes on such births. This suggests that local government policies and programs, such as 
special tax breaks aimed at stimulating firm births and local economic development, can have the desired effects if properly designed and implemented. Such policies should also help impede the revealed negative effects of firm deaths on births. Also of importance is the finding that a higher proportion of small firms and the presence of agglomeration economies have a positive causal effect on firm births and, hence, economic growth. This strengthens the case for policies designed to aid small firms and to promote the centralization of manufacturing activities. Finally, the finding that the quality of public education provided by the county's school districts enhances firm births should also be of interest to policy makers. As noted earlier, this finding suggests that manufacturing firms, prompted by the desire for a skillful and productive workforce, consider educational quality and all other educational benefits derived from school property taxes when making location decisions. Thus, policy makers, when raising such taxes, must make sure that such benefits are increased accordingly.

\section{REFERENCES}

Ashcroft, B., and J.H. Love. "Firm Births and Employment Change in the British Counties: 1981-89." Papers in Regional Science: The Journal of the RSAI 75 (4) (1996), 483-500.

Audretsch, D.B., and M. Fritsch. "Market Dynamics and Regional Development in the Federal Republic of Germany" Wissenschaftszentrum Berlin Discussion Paper FS IV (1992), 92-96.

Birley, S. "The Role of New Firms-Births, Deaths and Job Generation." Strategic Management Journal 7 (1986), 361-376.

Bradley, S., and J. Taylor. "Human Capital Formation and Local Economic Performance." Regional Studies 30 (1996), 1-14.

Carlino, G.A. Economies of Scale in Manufacturing Location: Theory and Measurement. Leiden: Martinus Nijhoff, 1978.

Carlino, G.A., and E.S. Mills. "The Determinants of County Growth." Journal of Regional Science 27 (1987), 39-54.

Cole, I.M. "Spatio-Temporal Variations and Interactions among Manufacturing Firm Births, Deaths, and Related Factors: The Case of Pennsylvania." Working Paper A11, Business and Economics Department, California University of Pennsylvania 1998.

Crone, T.M. "Where Have All the Factory Jobs Gone-and Why?" Federal Reserve Bank of Philadelphia Business Review (May/June 1997), 3-17.

Cross, M. New Firm Formation and Regional Development. Farnborough, UK: Gower, 1981.

Davis, S., J. Haltiwanger, and S. Schuh. "Small Business and Job Creation: Dissecting the Myth and Reasoning the Facts." Small Business Economics 8 (1996), 297-315.

Due, J.F. "Studies of State-Local Tax Influences on Location of Industry." National Tax Journal (1961), 163-173. 
Evans, L.B., and J.J. Siegfried. "Entry and Exit in United States Manufacturing Industries from 1977 to 1982." In D.B. Audretsch and J.J. Siegfried (eds.) Empirical Studies in Industrial Organization: Essays in Honor of Leonard W. Weiss, 253-273. Dordrecht: Kluwer Academic Publishers, 1992.

Fan, C.C. "The Temporal and Spatial Dynamics of Income and Population Growth in Ohio, 1950-1990." Regional Studies 28 (1994), 241-258.

Forkenbock, D., and N. Foster. "Highways and Business Location Decisions." Economic Development Quarterly 10 (3) (1996), 239-248.

Fox, W., and M. Murray. "Local Public Policies and Interregional Business Development." Southern Economic Journal 57 (1990), 413-427.

Fritsch, M. "Regional Differences in New Firm Formation: Evidence from West Germany." Regional Studies 26 (1992), 233-241.

Garofoli, G. "New Firm Formation and Regional Development: The Italian Case." Regional Studies 28 (1994), 381-393.

Granger, C.W., and P. Newbold. "Spurious Regressions in Econometrics." Journal of Econometrics 2 (1974), 111-120.

Gudgin, G. Industrial Location Processes and Regional Employment Growth. Farnborough, UK: Saxon House, 1978.

Hall, B.H. "The Relationship between Firm Size and Firm Growth in the U.S. Manufacturing Sector." Journal of Industrial Economics 35 (1987), 583-605.

Harris, C. "Small Business and Job Generation, Changing Economy or Differing Methodologies?" Brookings Institute Working Paper, Washington D.C., 1983.

Healy, M.J. "Firm Closures in Mullet-Firm Enterprises: The Case of a Declining Industrial Sector." Regional Studies 16 (1982), 37-51.

Highfield, R., and R. Smiley. "New Business Starts and Economic Activity: An Empirical Investigation." International Journal of Industrial Organization 5 (1987), 51-66.

Holtz-Eakin, D., W. Newey, and H.S. Rosen. "Estimating Vector Autoregressions with Panel Data." Econometrica 56 (1988), 1371-1395.

Hoover, E., and R. Vernon. Anatomy of a Metropolis. Cambridge, MA: Harvard University Press, 1959.

Howland, M. "Firm Closures and Local Economic Conditions." Regional Studies 22 (1988), 193-207.

Johnson, P., and G. Cathcart. "The Founders of New Manufacturing Firms: The Size of their Incubator Firms." Journal of Industrial Economics 28 (1979), 19-24. Johnson, P., and S. Parker. "Spatial Variations in the Determinants and Effects of Firm Births and Deaths." Regional Studies 30 (1996), 679-688.

. "The Interrelationships between Births and Deaths." Small Business Economics 6 (1994), 283-290.

Kalleburg, A.L., P.V. Marsden, H.E. Aldrich, and J.W. Cassel. "Comparing Organizational Sampling Frames." Administrative Science Quarterly 35 (4) (1990), 658-688. 
Keeble, D., and S. Walker. "New Firms, Small Firms and Dead Firms: Spatial Patterns and Determinants in the United Kingdom." Regional Studies 28 (1994), 411-427.

Kish-Goodling, D. Property Taxes and Local Economic Development: Pennsylvania, 1976-1980. New York: Garland Publishing, Inc., 1995.

Love, J.H. "Entry and Exit: County-Level Analysis" Applied Economics 28 (1996), 441-451.

Marshall, A. Principles of Economics. 8th ed., reset. London: Macmillan, 1949.

McNamara, K.T., W.P. Kriesel, and B.J. Deaton. "Manufacturing Location: The Impact of Human Capital Stocks and Flows." The Review of Regional Studies 18 (1988), 42-48.

Oxenfeldt, A.R. New Firms and Free Enterprise. Washington, D.C.: American Council on Public Affairs, 1943.

Reynolds, P. "Autonomous Firm Dynamics and Economic Growth in the United States, 1986-1990." Regional Studies 28 (1994), 429-442.

Reynolds, P., D.J. Storey, and P. Westhead. "Cross-National Comparisons of the Variation in New Firm Formation Rates." Regional Studies 28 (1994), 443-456.

Sims, C.A. "Macroeconomics and Reality." Econometrica 48 (1980), 1-48.

Stafford, H.A., and Qiutao Wu. "Manufacturing Firms in Ohio: Spatial Changes, 1978-87." Economic Development Quarterly 6 (3) (1992), 273-285.

Storey, D.J., and A.M. Jones. "New Firm Formation: A Labor Market Approach to Industrial Entry." Scottish Journal of Political Economy 34 (1987), 37-51.

Wasylenko, M. "Taxation and Economic Development: The State of the Economic Literature." Federal Reserve Bank of Boston New England Economic Review (March/April 1997), 37-52.

White, H. "A Heteroskedasticity-Consistent Covariance Matrix Estimator and a Direct Test for Heteroskedasticity." Econometrica 4 (1980), 817-834.

Whittington, R.C. "Regional Bias in New Firm Formation in the U.K." Regional Studies 18 (1984), 253-256.

Williams, M.L. "Measuring Business Starts, Success and Survival: Some Database Considerations." Journal of Business Venturing 8 (1993), 295-299. 